\title{
A Psychodynamic Formulation: The Case of Iron Man
}

\author{
Seungrie Han and Kyungmin Park \\ Department of Psychiatry, Yong-In Mental Hospital, Yongin, Korea
}

정신역동적 공식화: 아이언맨 사례

\author{
한승리 · 박경민 \\ 용인정신병원 정신건강의학과
}

Psychodynamic formulation is a hypothesis about how a person's unconscious thoughts, feelings, and impulses cause current mental difficulties, problems, and behavioral patterns. As well as functioning as a diagnostic map, it guides every aspect of the treatment in psychiatric clinical settings. Although the psychodynamic formulation would always be an essential part of psychiatric training, the methodology and its applications have not been actively presented. In this paper, we present one sample formulation using a movie character "Tony Stark" (well known as "Iron man" in the Marvel films). This study explores the possibility of applying the movie character to formulation training. Also, this study illustrates the value of psychodynamic formulation as a promising hermeneutic tool for aesthetic insight as well as a clinical tool.

Psychoanalysis 2020;31(1):11-21

KEY WORDS: Psychodynamic formulation · Iron man · Tony Stark.

Received: November 12, 2019 Revised: November 29, 2019 Accepted: December 6, 2019

Address for correspondence: Kyungmin Park, MD

Department of Psychiatry, Yong-In Mental Hospital, 940 Jungbu-daero, Giheung-gu, Yongin 17089, Korea

Tel: +82-31-288-0114, Fax: +82-31-288-0107, E-mail: falseself@naver.com

\section{서 론}

정신적 어려움을 겪고 있는 환자를 돕기 위해서는 환자의 사례를 이해하고 설명하는 시도, 즉 사례 공식화(case formulation)가 필요하다. 하나의 사례를 수많은 이론과 개념으 로 각각 설명할 수 있다. 그중 정신역동적 공식화(psychodynamic formulation)는 "한 사람의 무의식적인 사고와 감 정이 그로 하여금 치료로 이끌었던 어려움들을 유발시키는 방식에 관한 가설"(Cabaniss 등 2013)로서 주로 프로이트와 그의 후학들에 의해 제안된 정신분석 이론들에 근거하여 구 성되는 사례 공식화의 한 유형이다. 한 환자를 깊이 이해하 기 위해서는 사례 공식화가 큰 도움이 된다. 그러나 좋은 사 례를 실제로 보게 되는 일은 자주 있지 못하다. 그런 면에서 영화, 소설과 같은 창작물을 사례로 상정하고 사례 공식화를 해보는 것은 이후에 실제 사례를 공식화하는 데 많은 도움 이 된다.

This is an Open Access article distributed under the terms of the Creative Commons Attribution Non-Commercial License (https://creativecommons.org/licenses/by-nc/4.0) which permits unrestricted non-commercial use, distribution, and reproduction in any medium, provided the original work is properly cited.
본 논문의 목적은 정신역동적 공식화를 영화 속 한 인물 의 사례, 구체적으로는 미국 영화 제작사인 마블 스튜디오의 여러 작품들 속에 제시된 토니 스타크(Tony Stark, 아이언맨 으로 잘 알려져 있는 인물)의 사례에 적용하는 데 있다. 실제 환자의 사례를 대상으로 하는 정신역동적 공식화는 임상적 필요성에 의해 정당화될 수 있을 테지만 작품 속 인물의 사 례를 대상으로 하는 정신역동적 공식화가 과연 정당화될 수 있는지, 다시 말해 이러한 정신역동적으로 이해하려는 시도 가 어떠한 필요성에 의해 요청되는지 의문이 제기될 수 있 다. 사실 이러한 유형의 정신역동적 공식화를 최초로 시도한 자는 정신분석학의 창시자 프로이트다. 그는 『Some character-types met with in psycho-analytic work(정신분석 작 업에서 경험되는 몇몇 성격 유형)」에서 셰익스피어의 '맥베 스'와 입센의 '로스메르스홀름'을 작업한 적이 있다. 프로이 트는 이러한 자신의 시도에 대하여 "환자들의 인격을 존중 해야 하기 때문에 $\cdots$ (사례를) 중심으로 해서 다루고 싶지는 않다. 그래서 인간의 영혼에 대한 작가들의 풍부한 학식이 탄생시킨 허구적인 인물들에서 출발해 이 문제를 살펴보고 자 한다"고 언급하였다(Freud 1916). 프로이트는 정신분석 을 자연과학의 한 분야로 규정하며 일생 동안 직접 환자들 
을 만나며 실제로 행하고 모은 정신분석 데이터, 즉 경험적 사례들에 근거하여 입증하였다. 그러나 때론 허구적 인물들 의 사례를 소재로 삼아 자신의 이론을 지지하는 구체적 예 로 활용하였던 것이다.

본 논문이 영화 속 한 인물에 대한 정신역동적 공식화 과 정을 제시하는 하나의 성공적인 본보기(template)가 된다면, 이러한 접근법은 여러 이유들에 의하여 다양하게 활용될 수 있다고 생각한다. 하나는 예술 작품에 대한 이해를 위하여 활용되는 것이다. 이미 프로이트는 정신 기능의 두 가지 원 칙에 대한 가설을 제시하는 과정에서 "예술은 아주 독특한 방식으로 쾌락 원칙과 현실 원칙, 이 두 원칙을 화해시킨다" (Freud 1911)고 언급한 적이 있다. 예술 작품 속에는 정신분 석학이 발견한 인간 심리에 대한 통찰이 내재되어 있다는 프로이트의 주장을 인정할 수 있다면, 영화를 포함한 예술 작품들에 대하여 정신역동적 공식화를 이용하여 접근하는 시도가 예술에 대한 이해에 기여할 수 있다는 주장 역시 인 정할 수 있을 것이다. 또 다른 한 예는 정신역동적 공식화를 배우고 연습하는 과정을 위하여 활용하는 것이다. 정신역동 적 공식화는 교육수련 과정에서 실제 환자의 사례를 대체할 수는 없겠지만, 가상현실을 기반으로 비행훈련을 받기도 하 는 조종사의 경우처럼 교육 목적을 포함해 다양한 이유로 활용할 수도 있다. 이런 맥락에서 가상의 사례에 대한 정신 역동적 공식화는 의미가 있고, 본 연구의 필요성이 충분하다 고 생각한다.

\section{영화 및 정신역동적 공식화}

\section{영화(Movies)}

연구자는 마블 스튜디오에서 제작되어 국내에서 개봉한 15 개의 영화를 이용하였다(Table 1). 인용한 영화들은 등장 인물 토니 스타크를 묘사하고 그와 관련된 정보를 직간접적 으로 제공하고 있다. 마블 스튜디오에서 제작되는 많은 수의 영화들은 작품 속 인물, 배경, 줄거리 등을 공유하는 하나의 유기적인 세계를 그려내고 있는데 이 세계를 마블 시네마틱 유니버스(Marvel cinematic universe)라고 부른다. 토니 스 타크는 마블 시네마틱 유니버스를 구성하는 작품들 가운데 첫 번째 작품인 영화 ‘아이언맨'에서 처음으로 등장한 슈퍼 히어로이다. 천재 공학자이자 세계 최고의 군수업체 스타크 인더스트리의 최고경영자인 토니 스타크는 아프가니스탄에 서 신무기 발표를 성공적으로 마치고 돌아오던 중 테러리스 트들에게 납치되어 그들을 위한 무기를 개발하라는 협박을 받는다. 토니 스타크는 테러리스트들을 위한 무기 대신에 탈 출을 위한 철제 갑옷(최초의 아이언맨 슈트인 Mark I)을 몰
Table 1. Movie lists

\begin{tabular}{|c|c|}
\hline Film & Directed by \\
\hline 2008 Iron man & Jon Favreau \\
\hline 2008 The incredible Hulk & Louis Leterrier \\
\hline 2010 Iron $\operatorname{man} 2$ & Jon Favreau \\
\hline 2011 Thor & Kenneth Branagh \\
\hline 2012 The Avengers & Joss Whedon \\
\hline 2013 Iron man 3 & Shane Black \\
\hline $\begin{array}{l}2014 \text { Captain America: } \\
\text { the winter soldier }\end{array}$ & Anthony Russo, Joe Russo \\
\hline 2015 Avengers: age of Ultron & Joss Whedon \\
\hline 2015 Ant-man & Peyton Reed \\
\hline 2016 Captain America: civil war & Anthony Russo, Joe Russo \\
\hline 2017 Spider-man: homecoming & Jon Watts \\
\hline 2017 Thor: Ragnarok & Taika Waititi \\
\hline 2018 Avengers: infinity war & Anthony Russo, Joe Russo \\
\hline 2019 Avengers: endgame & Anthony Russo, Joe Russo \\
\hline 2019 Spider-man: far from home & Jon Watts \\
\hline
\end{tabular}

래 만드는 데 성공하고 평화를 수호하는 슈퍼 히어로인 아 이언맨으로 새롭게 다시 태어난다.

\section{정신역동적 공식화(Psychodynamic formulation)}

저자들은 단행본인 ${ }^{\circledR}$ Psychodynamic formulation $₫(\mathrm{Ca}-$ baniss 등 2013)에서 제시된 정신역동적 공식화의 방법론을 사용하였다. Cabaniss 등(2013)은 정신역동적 공식화 과정 을 세 가지 단계로 분류하고 이 단계를 순서대로 시행하여 "어떤 인물이 자신의 사고, 감정, 행동의 특징적인 패턴을 어 떻게 발달시켜 왔는지 또한 왜 그렇게 발달시켜야만 했는 지” 이해할 수 있다고 기술하고 있다. 본 연구에서 이용된 정신역동적 공식화의 과정을 Table 2에서 정리하여 제시하 였다.

\section{결 과}

\section{개요(Overview)}

정신역동적 공식화의 과정은 기본 세 단계로 이루어진다. 첫 단계는 환자의 주요 어려움, 문제, 행동 양상을 기술 (describe)하고, 다음으로 발달 및 과거력을 검토(review)한 뒤, 마지막으로는 정신역동적 이론을 활용하여 어려움, 문제, 행 동 양상을 발달 및 과거력과 연결(link)한다. 연구자도 본 연 구 결과를 기술하기(describe), 검토하기(review), 연결하기 (link)의 순서대로 제시하고, 마지막으로 치료적 적용에 대 해 기술하였다. 
Table 2. Three basic steps of psychodynamic formulation

\begin{tabular}{|c|c|c|}
\hline Step & What to do & Major concerns \\
\hline $\begin{array}{l}\text { Step } 1 \\
\text { Describe }\end{array}$ & Describe the primary problems and patterns & $\begin{array}{l}\text { Five basic areas of function } \\
\text { - Self } \\
\text { - Relationships } \\
\text { - Adapting } \\
\text { - Cognition } \\
\text { - Work and play }\end{array}$ \\
\hline $\begin{array}{l}\text { Step } 2 \\
\text { Review }\end{array}$ & Review the developmental history & $\begin{array}{l}\text { Before birth: family of origin, prenatal development, } \\
\text { genetic endowment } \\
\text { Earliest years of life: attachment, early relationships with } \\
\text { caregivers, trauma } \\
\text { Middle childhood } \\
\text { Later childhood, adolescence, adulthood }\end{array}$ \\
\hline $\begin{array}{r}\text { Step } 3 \\
\text { Link }\end{array}$ & $\begin{array}{l}\text { Link the problems and patterns to the history using } \\
\text { organizing ideas about development }\end{array}$ & $\begin{array}{l}\text { - Trauma } \\
\text { - Early cognitive and emotional difficulties } \\
\text { - Conflict and defense } \\
\text { - Relationships with others } \\
\text { - The development of the self } \\
\text { - Attachment }\end{array}$ \\
\hline
\end{tabular}

기술하기(Describe)

\section{자기(Self)}

\section{자기 지각(Self-perception)}

(1) 정체성(Identity)

토니 스타크(이하 '스타크'로 표기)는 비교적 안정적이고 확고한 정체성 감각을 지니고 있다. 스타크는 자신이 무엇을 좋아하는지(발명과 조립, 여자, 세계 및 우주 평화와 안전 등) 그리고 무엇을 싫어하는지(누군가에게 무언가 직접 건 네받는 것, 악당 등) 잘 알고 있으며, 자신의 재능(뛰어난 지 능, 창의성 등)과 한계(인간이라는 한계, 물론 자신이 만든 기술로 끝없이 한계를 돌파하려 하지만)에 대해 잘 알고 있 다. 아이언맨이 되기 전 스타크는 자신의 흥미와 관심을 따 라 대학에서 공학을 전공하여 우수한 성적을 거두었고 성공 적인 발명가로서의 이력을 쌓아가고 있었다. 스타크는 아이 언맨이 된 후 세계 및 우주 평화와 안전을 지키는 수호자를 자처하며 그 역할을 충실히 수행한다.

(2) 자기에 관한 공상(Fantasies about the self)

인피니티 전쟁(우주 전체가 인구의 과잉으로 균형을 잃었 다고 판단한 악당 타노스가 우주의 힘이 응축되어 있는 인 피니티 스톤 여섯 개를 모아 우주 생명체 절반을 무작위로 제거하려 하자 스타크를 포함한 어벤져스가 이를 막으려 하 였으나 결국 패배하게 된 전쟁) 이후에 발생한 스타크의 무
기력감과 우울감은 피터 파커(스파이더맨)를 포함한 많은 동료들과 우주 절반의 생명체들의 죽음과 상실에 따른 애도 반응(mourning)을 넘어, 세계 및 우주 평화와 안전이라는 이상과 가치의 실패와 수호자가 되고 싶다는 포부의 좌절에 따른 우울 반응(melancholia)으로 해석한다. 이러한 우울 반 응은 위로와 목표, 탈출구의 역할을 한 자기에 관한 무의식 적 공상의 좌절에 대한 반응이었다.

자존감 조절(Self-esteem regulation)

(1) 자존감 위협에 대한 취약성(Vulnerability to selfesteem threats)

자신이 발명한 무기들을 팔며 부와 명예를 얻었던 스타크 는 테러리스트들에게 납치되었을 때 무기들이 세계 평화를 위해 이용되고 있던 것이 아니라 약자를 억압하고 학살하는 데 이용되고 있다는 것을 목격하고 좌절감을 느낀다. 스타크 가 슈트를 개발하려는 것은 의식적으로는 탈출을 위해서지 만, 무의식적으로는 손상되고 좌절된 무의식적 상상을 복원 하고, 슈트를 만들어 자존감을 복구하려는 노력이었다.

(2) 자존감 위협에 대한 내적 반응(Internal response to self-esteem threats)

(1) 보다 덜 적응적인 내적 반응들(Less adaptive internal responses)

스타크는 자존감 위협에 대해 자신의 자기 감각(one's sense of self)을 부풀려(inflating) 대응한다. 스타크가 보이 
는 과대성(grandiosity)은 스타크가 자신의 한계와 결점 그 리고 실수 등을 직면할 때 발생되는 고통으로부터 스타크를 보호해 준다. 다음은 이를 예시하는 영화 ‘아이언맨' 초반부 의 한 장면이다. 군수업체의 성공적인 운영으로 미국의 국익 에 기여한 공로를 인정받아 수상식에 참가한 스타크에게 한 기자가 다가와 군수산업의 어두운 그늘을 비난한다. 그녀는 "세상 사람들이 스타크를 '현 시대의 다빈치(the da Vinci of our time)'라고 부르지만 동시에 '죽음의 상인(the merchant of death)'이라고 부르기도 한다"고 조롱하듯 애기한다. 스타 크도 군수산업에 종사하는 자신에 대한 세간의 비난을 영 모르는 것은 아니다. 단지 그는 자신의 그림자를 회피하고자 하며 극소화하고 싶어할 뿐이다. 그러나 자신의 그림자를 응 시하는 직면(confrontation)은 고통을 초래할 것이므로, 스 타크는 자신의 공을 극대화하여 실을 덮고자 한다. 스타크는 기자에게 '평화란 결국 상대방보다 더 큰 무기를 지니고 있 는 것("Peace means having a bigger stick than the other guy”)'이라고 여겼던 자신의 아버지 하워드 스타크의 신념에 대해 들려준다. 아버지가 맨해튼 프로젝트(제2차 세계대전 중 미국과 그 동맹국의 과학자들이 참여한 핵폭탄 개발 프 로젝트)에 참여하여 나치를 물리치는 데 기여하였기에 세상 사람들이 영웅이라고 부르게 되었다는 맥락이었다. 영웅인 아버지와 동일시하는 스타크는 군수산업이야말로 질병과 기아 문제의 해결을 위한 의료와 식량 기술 발전을 지원하 는 밑거름이라며 비난에 대응한다(“Tell me, do you plan to report on the millions we've saved by advancing medical technology or kept from starvation with our intelli-crops? All those breakthroughs, military funding, honey"). 애국자 이자 평화의 수호자임을 자처하며 자신의 역할과 기여도, 그 리고 인류애를 과시하는 형태로 표출하는 스타크의 과대성 (grandiosity)은 전쟁 무기이든 아이언맨 슈트이든 그가 창 조한 테크놀로지의 양면성으로 인한 한계와 결점이 유발하 는 고통(예컨대, 죄책감)으로부터 스타크를 보호해 준다. 맨 해튼 프로젝트에 참가한 과학자들이 나치즘, 파시즘, 군국주 의 등을 격퇴한 영웅으로 추앙되기도 했지만 일부는 핵폭탄 으로 희생된 민간인들에 대한 죄책감에 시달렸다.

스타크는 자신의 실패를 외부 원인으로 돌리는 경향이 있 으며 쉽게 격분하고, 요구적이며 타인을 과소평가한다. 이는 자기애적 성향으로 자존감을 보호하지만, 타인과의 관계가 희생된다는 것을 알아차리지 못하기 쉽다.

(2) 보다 더 적응적인 내적 반응들(More adaptive internal responses)

스타크는 자존감 위협에 대해서 보다 더 경쟁적인 모습으 로 대응한다. 어벤져스 내에서 스타크의 중요도가 높고 실력
도 좋기는 했지만, 스타크가 보여주는 매너와 잘난 척하는 태도 때문에 많은 어벤져스 구성원들이 그와 함께 일하는 것 에 대해서 어벤져스 결성 초기에는 불편감을 표현하곤 했다.

스타크는 차갑고 계산적인 자신의 아버지로 인해 그 반대 의 모습을 지닌 아버지를 늘 그리워한다. 스타크는 아버지로 부터 버림받은 할리 키너와 아버지가 일찍 사망한 피터 파 커에게 선물들(할리 키너에게는 작업실, 피터 파커에게는 슈트)을 제공하며 좋은 아버지 역할을 하려 했던 것 같다. 이 러한 행동들이 좌절감으로부터 그를 보호하였을 것으로 추 측된다.

(3) 자존감 조절을 돕기 위해 타인들을 이용(Use of others to help regulate self-esteem)

스타크는 자존감을 조절하기 위해서 타인들로부터 지속 적인 관심과 칭찬 그리고 인정을 필요로 한다. 스타크는 칭 찬을 유도하고 반복적으로 인정을 요구하며 스스로 관심의 중심에 서려 한다. 스타크는 마치 타인들이 오직 자신의 자 존감을 키우기 위해서만 존재하는 것처럼 행동하기도 하는 데 이는 공감(empathy)의 부족을 시사한다.

\section{관계(Relationships)}

\section{신뢰(Trust)}

스타크는 다른 사람들에 대한 믿음이 없었으나 시간이 흘 러가며(마블 영화 시리즈의 초기에서 후기로 진행하며) 점 차 신뢰가 형성되고 발달되어 가는 것으로 보인다. 아이언맨 이 되기 전이나 되고 난 초기에는, 스타크는 깊고 오랜 연인 및 동료 관계를 형성하지 못하였다. 스타크는 수많은 여인들 과 하룻밤의 짧은 관계만을 즐기고 헤어지기를 반복하였다. 하지만 페퍼 포츠와 연인 관계를 맺은 뒤에는, 헌신하여 그 와 결혼하고 자식을 낳아 양육하였다. 이는 보다 깊은 관계 를 형성하고 유지하는 능력이 발달하고 발전한 것으로 보인 다. 동료 관계에 있어서도 초기에는 협력하기보다는 홀로 임 무를 수행하는 경향을 보였다. 하지만 나중에는 어벤져스 구 성원들과 서로 의지하며 함께 문제를 해결해가는 경향을 보 이는데, 이 또한 동료 관계(peer relation)를 단단하고 믿을 수 있는 것으로 인식하게 된 것으로 볼 수 있다.

자기와 타인에 대한 감각(Sense of self and other)

스타크는 두드러진 분리(splitting)의 사고방식을 보인다. 이는 스타크가 자신을 적대시 대하는 인물(오베디아 스탠, 이반 반코, 알드리치 킬리언 등)에 대해서 두드러지는데, 이 들을 전적으로 선하거나 혹은 악하다고 보는 경향이 있다. 
스타크는 이들을 자신과 독립된 별개의 존재로 인식하지 못 했고, 자신을 따르지 않으면 곧 적으로 받아들이는 양상을 보였다.

\section{안정감(Security)}

스타크는 관계에서 안정감을 느끼지 못한다. 안정감 $\left(\mathrm{se}^{-}\right.$ curity)이란 안전한 상태(the state of being safe)를 가리킨 다. 또한 관계에서의 안정감이란 다른 사람에게서 안전하다 고 느끼는 것(feeling safe with another person)을 말한다. 즉 물리적인 이별(physical separations)이나 불일치(disagreements), 그리고 부정적인 느낌들(other negative feelings)과 같은 상황에서 스타크는 그 관계가 지속될 것이라고 느끼지 못한다. 스타크는 발달적으로 불안정 애착(insecure attachment)을 경험한 것으로 보인다. 스타크는 타인들에 대 해 다양한 양가감정을 받아들이기 어려워하며, 지속적인 관 계를 맺기 어려워한다. 페퍼 포츠, 해피 호건 등 스타크와 오 랜 관계를 맺고 있는 이들은 스타크의 필요(needs)를 충족시 켜주는 특정 기능을 수행하는 이들이 대부분이다.

\section{친밀감(Intimacy)}

스타크는 자신에 관한 개인적인 것들을 대부분 타인들과 공유하려 하지 않고 친밀감을 강화하려 하지 않는다. 친밀감 은 가까움(closeness)과 친숙함(familiarity), 사적인 견해와 느낌을 공유하는 것을 의미한다. 친밀감은 한 개인과 대상과 의 관계에서 그 개인을 안정되고 편안하게 만들 수도 있고, 반대로 불안하고 상처받기 쉽게 만들 수도 있다. 스타크는 극소수의 대상을 제외하고는 거리를 두려고 한다. 이러한 스 타크의 모습은 그가 이러한 친밀감을 애초부터 회피하는 모 습을 보이는 것으로 생각할 수 있다.

\section{상호성(Mutuality)}

두 사람이 서로 주고받을 수 있을 때 관계는 상호 관계적 이라고 할 수 있다. 이러한 면에서 스타크의 인간 관계를 살 펴보면 대개 스타크는 받기만 하고 타인들은 주는 것처럼 보인다. 스타크는 받는 사람으로서 공감의 능력이 부족하여 다른 사람들의 욕구를 개의치 않는다.

\section{적응하기(Adapting)}

방어 기제(Defense mechanisms)

스트레스에 적응하는 무의식적인 방식을 방어(defenses) 라고 부를 수 있다. 스타크는 스트레스를 관리하기 위해서 자신만의 방어를 사용하는데, 스트레스 상황에서 학업이나
지적인 작업 그리고 창의적인 발명과 조립에 몰두한다. 이러 한 스타크의 모습은 주지화(intellectualization), 승화(sublimation)의 방어기제를 보여준다. 스타크의 방어들은 스타크 의 기능을 유지하거나 향상시키는 방향으로 대체로 적응적 인 역할을 수행한다. 또한 스타크는 악당들을 마주할 때 분 열(splitting), 부정(denial)이라는 방어기제를 사용하여 자신 에 대한 좋은 느낌을 유지하기 위해 애쓴다. 이러한 방어 전 략들은 스타크의 기능을 유지하는 데 도움이 되는 면이 있 지만 자신의 성숙과 통찰, 나아가 타인과의 건강한 관계를 방해한다는 점에서 비적응적인 면도 있다. 끊임없는 슈트의 개발과 업그레이드에만 몰두하고, 슈트를 이용하여 자신을 보호하려 애쓰는 스타크의 모습은 방어 전략이 일관되지만 경직된 측면이 있음을 보여준다. 이러한 방어 전략은 스타크 의 불안 수준을 견딜 수 있는 범위 내에서 유지시켜 주기 때 문에 평소에는 전반적으로 도움이 된다. 그러나 뉴욕 전투의 핵 위기처럼 슈트로도 막을 수 없는 붕괴(disintegration) 혹 은 소멸(annihilation)의 위험에 마주했을 때는 이러한 방어 가 무력해지고 불안 수준이 높아져 스타크의 일상 전반에 부 정적인 영향을 미친다.

\section{정서 관리(Managing emotions)}

스타크의 일상 생활을 관찰하였을 때, 다양한 범위의 감정 을 경험하고 대체로 이를 적절히 표현할 수 있는 것으로 보 인다. 아프가니스탄에서 피랍되었을 때 스타크는 수치심, 죄 책감, 그리고 분노 등의 감정을 경험하였다. 절망스런 상황 에서도 자신의 감정을 대체로 침착하게 관리하고 분별력 있 게 대응하는 모습을 보여주었다.

\section{충동 통제(Impulse control)}

스타크는 대체로 충동 조절을 잘 수행하는 편이다. 충동을 통제하는 데 어려움을 겪는 이들은 식욕 관리, 도박, 공격성/ 폭력성 통제, 도벽 등의 영역에서 어려움을 표현하곤 하는데 스타크는 이에 해당하지 않는 것으로 보인다.

\section{감각 조절(Sensory regulation)}

스타크는 자신을 과시할 수 있는 무대, 신제품 발표회, 기 자 회견 등과 같이 매우 자극적인 환경을 즐기곤 하며 다양 한 감각 자극에 적응하는 모습을 보인다.

\section{인지(Cogntion)}

일반적인 인지 능력(General cognitive abilities)

스타크는 지능, 기억력, 집중력, 말하기 및 언어 능력 등의 
전반적인 영역에서 매우 뛰어난 인지 능력을 지니고 있다.

결정 내리기와 문제 해결하기(Decision making and problem solving)

스타크는 때로는 즉흥적이며 빈번하게 마음을 바꾸고 감 정적인 방식으로 결정을 내릴 때가 있다. 하지만 문제를 해 결하는 과정에 있어서 대체적으로 매우 조직적이고 창의적 인 방식으로 접근하는 편이다.

자기 성찰과 현실 검증력(Self-reflection and reality testing) 스타크는 자신의 경험으로부터 뒤로 물러서서 그것을 이 해하기 위해 노력하는 능력, 즉 자기 성찰(self-reflection)이 부족한 편이다. 자기 성찰은 심리적 마음가짐(psychological mindedness)과 관련이 있으며 자신의 생각, 느낌, 행동의 무 의식적 동기에 대해 생각할 수 있는 능력을 뜻하기도 한다. 스타크는 알드리치 킬리언이 왜 자신에게 원한을 품고 악당 이 되었는지, 자신이 어떻게 이러한 상황에 기여하게 되었는 지를 처음에는 이해하지 못한다. 심리적 마음가짐이 부족하 여 자기 성찰을 할 수 없었던 스타크는 자신에게 문제가 있 다는 것을 나중에서야 깨달을 수 있었다. 스타크가 인용하는 글귀인 "We create our own demons(우리는 각자의 악마를 만들어 낸다)”에는 그동안 자신이 싸워온 악당의 모습이 스 스로 분리(splitting), 투사(projection)시켜 온 이미지라고 말 하는 자기 성찰적 고백이 반영되어 있다. 이러한 부분을 보 면 초기에는 심리적 마음가짐이 부족했지만 여러 극적인 계 기로 이루어진 성장 과정을 통해 통찰(insight)이 형성되고 심리적 마음가짐이 발달되는 것을 확인할 수 있다.

마음 헤아리기(Mentalization)

마음 헤아리기는 타인들이 자신과는 다른 생각과 느낌을 가질 수 있다고 이해하는 능력이며, 마음을 헤아리는 능력은 다른 사람을 공감하는 능력의 핵심이다. 스타크는 타인들의 사고와 감정을 이해하기 어려워하였으며 자신의 행동이 타 인들에게 어떤 마음을 불러일으킬지 예상하지 못하였다.

판단(Judgment)

스타크는 행동의 결과를 고려하는 판단 능력에 있어서 인 지적으로나 도덕적으로 대체로 올바른 판단을 내리는 편이 다. 하지만 때로는 순간의 감정에 휩쓸려 그른 판단을 할 때 도 있었다.

\section{일과 놀이(Work and play)}

스타크는 무기 발명가이자 군수 사업가로서의 일을 한다.
스타크의 일은 그의 발달 수준, 교육, 재능, 한계와 잘 맞는 편이며 편하고 즐거우며 만족스럽다. 또한 자신과 다른 가족 을 돌보기에 적합하며 문화적으로 용인될 만하다. 스타크는 보디가드이자 놀이 친구인 해피 호건과 자동차 경주를 한다 든지, 새롭게 개발한 아이언맨 슈트를 시험해 본다든지 하는 등의 놀이를 한다. 스타크의 놀이는 유아적인 측면이 있고, 즐거우며 만족스럽고 문화적으로는 용인될 만한 편이지만 때론 위험하기도 하여 자신과 다른 가족을 돌보기에 적합하 지는 않다.

\section{검토하기(Review)}

유전 및 산전 발달, 생의 초기, 중기 아동기(Genetics and prenatal development, the earliest years, middle childhood)

1970년 5월, 스타크는 유명한 발명가이자 군수산업 회사 를 운영하였던 아버지와 어머니 사이에서 정상 만기 자연분 만으로 출생하였으며 출생 당시 외상이나 기형의 소견은 없 었다. 스타크는 외아들로 wanted baby였고 모유를 먹고 잔 병치레 없이 건강하였으며 언어와 행동 발달상의 이상 없이 자랐다.

1974년(4세), 스타크는 일로 바빴던 아버지, 어머니와 같 이 있는 시간이 많지 않아 유모의 돌봄을 받으며 자랐다. 아 버지와 함께 놀고 싶었던 스타크는 때로는 아버지에게 장난 을 치기 위해 아버지의 작업실에 몰래 들어갈 때도 있었지 만 발명과 자신의 일에만 몰두하는 아버지로부터 빨리 나가 라는 꾸중만을 듣곤 하였다. 스타크는 차라리 무언가를 만들 면서 시간을 보내는 것이 더 낫겠다는 생각에 혼자서 뭔가 를 만들거나 조립하는 일에 열중하기 시작했다. 스타크는 4 세에 전자 회로를 혼자서 직접 만들었다.

1976년(6세), 스타크는 또래 친구들과 어울려 노는 것보다 혼자 무언가를 만드는 것이 더 재미있다는 생각에 발명에 계속해서 집중하였다. 스타크는 6세에 처음으로 자동차 엔 진을 혼자서 직접 만들었다.

후기 아동기, 청소년기(Later childhood, adolescence)

1987년(17세), 스타크는 Massachusetts Institute of Technology(M.I.T.)를 최우등(summa cum laude) 졸업하였다.

\section{초기 성인기(Young adulthood)}

1991년(21세) 12월, 스타크는 아버지, 어머니가 크리스마 스 휴가 중 교통사고로 모두 사망하자 다시는 이들을 볼 수 없다는 생각에 슬픈 기분이 들었다. 아버지, 어머니가 여행 
을 떠나기 직전 집에서 짧은 만남이 있었던 스타크는 아버 지에게 사랑한다는 말 한마디 건네지 못하고 평소처럼 서로 에 대해 빈정대는 말만 주고받은 뒤 헤어졌다는 생각에 후 회스런 기분이 들었다. 자신을 단 한 번도 따스하게 대해준 적이 없었던 아버지를 미워해 온 스타크는 아버지의 죽음을 어떻게 받아들여야 할지 모르겠다는 생각에 몹시 괴로웠다. 스타크는 사망한 아버지의 회사를 물려받아 최고경영자가 되었으며 천재적인 무기 발명가이자 군수 사업가로서 성공 적인 이력을 쌓아 나갔고 수많은 여자들과 염문을 뿌리는 플레이보이로서의 생활을 즐겼다.

\section{후기 성인기(Later adulthood)}

2008년(38세), 스타크는 아프가니스탄 미군 기지에서 새 로운 미사일 발명품의 시연을 성공적으로 마치고 돌아오던 중 테러리스트들의 공격을 받아 납치되었다. 포탄의 파편이 심장에 박히게 된 스타크는 이미 오래 전 피랍되어 있던 외 과의사 인센 박사의 도움으로 목숨을 건질 수 있었다. 스타 크는 자기들을 위한 미사일을 만들어내라는 테러리스트의 협박보다도 자신이 그동안 세계 평화를 위해 만들었다고 생 각한 회사의 무기들이 악한 테러리스트들의 손에 이용되고 있다는 사실에 몹시 부끄럽고 죄스러운 기분이 들었다. 화가 난 스타크는 테러리스트들을 속여 미사일을 만들기 위한 재 료를 건네받은 뒤 아크 리액터(초소형 핵 융합 발전기)를 만 들어 심장 속 파편에 의해 자신이 분쇄되어 버리지 않도록 하였으며 이를 동력원으로 자신을 보호하고 적들을 공격할 수 있게끔 돕는 최초의 아이언맨 슈트를 제작하였다. 스타크 는 인센 박사의 희생으로 슈트를 이용하여 테러리스트들을 제압하고 성공적으로 탈출할 수 있었다. 미국으로 돌아와 기 자 회견을 연 스타크는 회사의 부회장인 오베디아 스탠의 반대에도 불구하고 사회적 책임을 위하여 자신의 군수 사업 을 중단하겠다고 선언했다. 스타크는 곧 스탠에 의해 회사의 최고경영자 직위에서 해임되었으며 그가 자신 몰래 회사의 무기들을 빼돌려 테러 조직들과 암거래해 왔다는 사실을 알 게 되었다. 스타크는 죽은 아버지의 오랜 동료로서 마치 좋 은 아버지처럼 자신의 능력을 인정해 주고 평화에 이바지하 고자 하는 자신을 늘 지지해 주어 왔다고 여겼던 스탠에게 오랫동안 속아왔다는 생각에 배신감과 분노를 느꼈다. 자신 과 페퍼를 죽이려 드는 스탠에 맞선 스타크는 서로 슈트를 착용한 채 치열한 싸움을 벌인 끝에 가까스로 스탠을 죽일 수 있었다. 아이언맨의 정체를 궁금해 하는 여론 분위기 속 에서 기자 회견에 임한 스타크는 거짓 알리바이를 애기하라 는 세계안전보장이사회 산하기관 쉴드의 지시에도 불구하 고 자신이 누구인지 밝혀 으스대고 싶다는 생각에 의기양양
하여 자신이 바로 아이언맨이라고 말했다.

2010년(40세), 스타크는 아이언맨 슈트를 착용한 자신의 모습에 환호하는 사람들을 보자 슈트를 입으면 무엇이든 할 수 있다는 생각에 흐뭇해져 슈트를 뽐내고 다녔다. 스타크는 자신이 있기에 세계 평화와 안전이 유지될 수 있다는 생각 에 들뜬 기분이 들었다. 아크 리액터의 팔라듐 독성으로 인 해 자신이 죽어가고 있다는 사실을 알게 된 스타크는 아크 리액터를 분리하고 심장 속 파편을 제거하는 수술을 선택할 수도 있었지만 슈트를 포기하고 평범한 사람으로 돌아갈 수 는 없다는 생각에 결연해져 수술을 받지 않았다. 스타크는 슈트가 테러리스트나 적에게 이용될 수 있다며 국가에 귀속 시키라는 정부의 요구에도 슈트의 핵심 기술인 아크 리액터 는 천재인 자신 외에는 누구도 모방하여 만들 수 없다는 생 각에 자신만만해져 큰소리를 치며 거절했다. 스타크는 죽은 아버지의 옛 동료로서 아버지와 함께 아크 리액터의 초기 모델을 만들었던 안톤 반코의 아들 이반 반코의 갑작스런 공격을 받게 되었다. 스타크는 색다른 유형의 아크 리액터 기술을 이용한 슈트를 입은 반코가 나타나자 자신의 기술은 독창적이며 그 누구도 따라할 수 없다고 여겼던 판단이 틀 렸을 수 있다는 생각에 몹시 당황스러워하며 그의 재능과 기술이 샘이 나기도 했다. 반코가 스타크 부자에 대하여, 반 코의 아버지와 스타크의 아버지가 공동으로 고안했던 아크 리액터 기술과 그 권리를 모두 빼앗고 그들이 누려야 할 명 예와 부를 전부 가져간 강도이자 살인자로 표현하며 몰아붙 이자 스타크는 혼란스러웠다. 아버지와 자신이 지향해 왔던 그 모든 이상과 가치 그리고 독창성이 거짓이자 허상일 수 있다는 생각이 들었기 때문이었다. 또한 스타크는 쉴드를 통 해 아버지가 자신에게 남긴 메시지를 새롭게 확인하며 그동 안 자신이 알고 있던 아버지와 실제 아버지가 다를 수도 있 다는 생각에 또한 혼란스러웠다. 결국 아버지가 남긴 아이디 어의 도움으로 스타크는 아크 리액터의 독성 물질을 교체한 뒤 가까스로 반코를 죽일 수 있었다.

2012년(42세), 스타크는 외계 종족이 지구를 정복하기 위 해 뉴욕에 쳐들어오자 우주 평화를 위해 싸우겠다는 생각에 한편으론 몹시 두렵기도 했지만 슈퍼 히어로들의 모임인 어 벤져스에 가입하였다. 어벤져스가 결성된 초기에는 혼자서 문제를 다 해결할 수 있다는 생각에 다른 히어로들과 자주 다투곤 했지만, 한 동료(필 콜슨)를 잃게 되고 공동의 적을 물리쳐야 하는 상황에 직면하자 스타크는 다른 사람들과 함 께 지혜와 힘을 모아야만 문제를 성공적으로 해결할 수 있 다는 것을 깨닫게 되었다. 그리고 다른 히어로들과 서로 의 지하며 외계 종족을 물리쳤다.

2013년(43세), 스타크는 뉴욕 전투의 핵폭발 위기로 인한 
외상적인 기억으로 고통을 받았다. 잦은 공황 발작과 불면 증상으로 어려움을 겪게 된 스타크는 여비서이자 동거녀이 기도 한 페퍼 포츠를 포함한 소중한 사람들을 잃고 싶지 않 다는 생각에 불안해져 아이언맨 슈트의 개발과 업그레이드 에 몰두하였다. 스타크는 신원을 알 수 없는 테러리스트들의 공격으로 보디가드인 해피 호건의 생명이 위태롭게 되자 늘 옆에 있던 친구를 영원히 잃어버릴지도 모른다는 생각에 몹 시 화가 나 비밀로 해왔던 집 주소를 테러리스트들에게 공 개하며 직접 찾아오라고 도발한다. 테러리스트들의 공격을 받아 집이 부서지고 아이언맨 슈트마저 고장이 나 그는 멀 리 떨어진 테네시 주에 불시착하게 되었다. 스타크는 슈트가 없으니 자신은 아무 것도 할 수가 없다는 생각에 무력해진 기분이 들었는데, 시골 마을에서 아버지로부터 버림받은 한 꼬마를 만나자 자신의 어릴 적 모습을 보는 것 같은 생각이 들었다. 스타크는 꼬마로부터 기계공이 아니냐며 뭐라도 만 들어 보라는 조언을 듣게 되자 슈트가 없어도 자신이 뭔가 해볼 수 있다는 생각에 의욕이 솟아 손수 만든 각종 도구들 을 이용하여 테러리스트들의 기지에 잠입하였다. 오래전 자 신이 무심코 무시하고 모욕한 적이 있던 과학자 알드리치 킬리언이 테러리스트들의 배후에 있다는 것을 알게 된 스타 크는 그동안 업그레이드해 온 아이언맨 슈트들을 이용하여 가까스로 그를 죽일 수 있었다. 이후 심장 수술을 받아 파편 을 제거한 스타크는 슈트가 없어도 자신은 변함없이 아이언 맨이라는 생각에 자신감이 생겨 바다에 아크 리액터를 던져 버렸다.

2018년(48세), 스타크는 우주 속 생명체의 절반을 인피니 티 스톤을 이용하여 없애고자 하는 타노스에 맞서 어벤져스 구성원들과 함께 싸우게 되었다. 타노스에게 패배하고 아들 처럼 여겼던 피터 파커를 포함한 많은 소중한 동료들을 잃 어버린 스타크는 지금까지 자신이 추구해 온 우주의 평화와 안전이라는 이상과 가치 그리고 수호자가 되려는 자신의 포 부가 무너져 버렸다는 생각에 절망스런 기분이 들었다.

2023년(53세), 다섯 살 난 딸과 아내 포츠와 함께 소박한 삶을 살면서 인피니티 전쟁의 패배로 인한 슬픔을 잊으려 했던 스타크는 돌이킬 수 없다는 생각에 무력한 기분이 들 어 여가 시간에는 새로운 슈트의 개발과 업그레이드에 몰두 하곤 했다. 스타크는 핌 입자를 이용하여 과거로 돌아가 인 피티니 스톤을 모으면 타노스에 의해 잃어버린 모든 사람들 을 다시 살릴 수 있다는 것을 알게 되었다. 어벤져스 구성원 들과 함께 스톤을 구하기 위해 과거로 돌아간 스타크는 아 내의 출산을 앞두고서 사무실에서 너무 많은 시간을 보냈다 고 말하며 긴장된 모습으로 아빠가 될 자격이 있는지 염려 하는 아버지 하워드 스타크를 마주치게 되었다. 스타크는 아
버지로부터 그가 무언가 잘못했을 때 할아버지에게 벨트로 맞곤 했다는 이야기 그리고 앞으로 태어날 아이를 위해선 그는 무엇이든 할 수 있다는 이야기를 들었다. 아버지가 나 름대로 자신에게 최선을 다했다는 생각에 고마움을 느낀 스 타크는 아버지를 포옹하며 고맙다고 직접 말해 주었다. 이후 스타크는 어벤져스 구성원들과 함께 협력하여 인피니티 스 톤을 이용하여 5년 전 잃어버린 사람들을 모두 되살리게 되 었다. 분노하며 모든 생명체를 죽이려고 하는 타노스의 반격 에 맞선 스타크는 인피니티 스톤을 이용하면 자신이 죽게 될 것을 알고 있었지만 자신은 아이언맨이라고 말하며 스톤 을 이용하여 가까스로 타노스와 그의 일당들을 죽인 뒤 자 신도 죽음을 맞이하였다.

\section{연결하기(Link)}

\section{기술하기를 통해 알게 된 것 중 핵심적인 것을 추리기}

(Focusing what has been learned from describing)

스타크의 가장 큰 어려움, 문제, 패턴은 자기(self)의 영역 에서 두드러지게 나타난다. 스타크는 겉보기엔 남 부러울 것 없이 마치 모든 것을 다 가진 사람처럼 보인다. 그는 부와 지 성, 그리고 탁월한 재능과 같은 자신의 잘난 모습을 과도한 자신감과 거만한 태도로 남들에게 과시하기를 좋아한다. 그 는 일상에서 과대적(grandiose)이고 자기애적(narcissistic)인 성향을 노골적으로 드러낸다. 그러나 자존감(self-esteem)을 위협받게 되면 빠르게 불안해지거나 분노하거나 흔들리는 모습을 보인다. 이러한 상황들에서 그는 평소와는 다른 심한 정서적 격동을 경험한다.

다음의 장면들이 스타크의 이런 면을 잘 묘사한다.

1) 영화 ‘아이언맨'에서 ‘죽음의 상인'이라는 비난을 듣거나 자신이 만든 무기가 오용되고 있는 현장을 목격하였을 때.

2) '아이언맨 2'에서 반코가 자신을 강도와 살인자의 가문 출신으로 비난하였을 때.

3) ‘아이언맨 3'에서 자기대상(selfobject) 기능을 수행하던 보디가드 겸 놀이 친구인 해피 호건이 중태에 빠졌을 때.

4) '어벤져스: 인피니티 워'에서 타노스에게 패배하여 평 화의 수호자로서의 자신의 포부가 좌절되었을 때가 그러하 였다.

그리고 이 모든 상황은 자존감의 위협이라는 주제를 공유 한다. '자기 자신에 대해 좋은 느낌을 갖지 못하도록 위험에 빠뜨리는 것을 자존감 위협(self-esteem threat) 또는 자기애 적 손상(narcissistic injury)'(Cabaniss 등 2013)이라고 일컫 는데, 스타크는 자존감 위협에 취약한 면이 있다. 스타크는 심리적 현실(psychic reality)에서 자존감 유지에 대한 강한 
불안감을 보이고 있고, 이러한 불안을 슈트의 개발과 업그레 이드를 통해 지속적으로 방어하려 한다. 스타크는 자기대상 (selfobject) 기능을 수행하는 슈트를 착용함으로써 자신의 자기감(sense of self)을 강화하고 정체성(identity)을 유지하 려 애쓴다.

\section{검토하기를 통해 알게 된 것 중 핵심적인 것을 추리기}

(Focusing what has been learned from reviewing)

스타크의 발달 및 과거력에서 가장 문제적인 부분은 중기 아동기, 초기 성인기인 것으로 보이는데 특히 이른 죽음을 맞이한 아버지와의 관계가 핵심적인 이슈로 보인다. 이러한 판단의 근거는 스타크의 아버지 하워드 스타크의 양육 방식 에서 추정한다. 스타크의 아버지는 아들에게 공감적으로 대 해주지 못했다. 하워드 스타크는 연구실에 들어와 장난을 치 는 어린 스타크에게 냉담한 태도로써 큰소리로 야단을 치고, 유학 중 크리스마스 휴가를 맞이하여 모처럼 집에 돌아온 스타크에게 이 노숙자는 대체 누구냐며 빈정대었다. 아버지 는 아들을 늘 못마땅해 하고 굴욕을 주는 방식으로 대한다. 스타크는 마흔이 되어서야(영화 '아이언맨 2') 약 20년 전 죽 은 아버지의 엑스포 영상을 통해 아버지의 자신에 대한 뜻 밖의 애정 표현[“지금도 그러하고, 앞으로도 항상 그러할 것 인데, 내 최고의 작품은 바로 너란다(What is, and always will be, my greatest creation $\cdots$ is you”)]을 처음 접했을 뿐 이다.

건강한 자기의 발달은 공감적인 양육(empathic caregiving)에 달려 있다. 공감적인 양육자는 아이가 무엇을 생각하 고 느끼는지 정확하게 포착하여, 정서적인 면에서 잘 조율된 반응과 발달적인 면에서 적절한 반응으로 아이에게 돌려준 다. 이것을 반사(mirroring)라고 부른다. 또한 아이는 자신의 양육자에 대해 강하고, 좋고, 안전하다고 느끼며 양육자를 이상화(idealizing)할 필요가 있다. 반사와 이상화는 건강한 자존감의 발달에 필수적이다. 이러한 반사와 이상화라는 중 요한 기능을 묘사하는 것이 바로 '자기대상(selfobject)'이라 는 용어이다(Cabaniss 등 2013). 양육자는 아이에게 적절한 자기대상이 되어 주어야 한다.

아버지가 적절한 자기대상의 기능을 수행하지 못하고 아 이에게 공감적으로 반응해 주지 못하고, 이것이 가끔 일어나 는 일시적인 실패가 아니라 만성적이고 지속적인 방식으로 반복된다면, 이 아이에게서 자기의 발달이 건강하고 적절하 게 진행될 것이라고 기대하기는 어려울 것이다. 스타크와 아 버지 하워드 스타크의 문제적 관계는 하워드 스타크가 사망 한 이후에도 지속적으로 스타크의 인생에 영향을 미친다. 스 타크는 악당들(오베디아 스탠, 이반 반코, 알드리치 킬리언,
타노스 등)과 싸우는 과정을 통하여 이러한 싸움을 성장의 계기로 만들었다. 아버지와의 문제적 관계로 인하여 아동 및 성인기에 완성되지 않고 고정된 자기의 발달 과정은 매 계 기마다 끊임없이 재활성화를 요구하였다. 스타크가 죽기 직 전까지 아버지인 하워드 스타크의 이미지가 계속해서 수정 되는 것을 거듭하는 것이 아버지상의 재활성화와 변화가 있 었음을 시사한다.

스타크의 발달 및 과거력에서 스타크 부자의 관계가 검토 하기(review)의 핵심적인 이슈라는 판단의 또 다른 근거는 스타크가 뉴욕 전투의 핵 위기 이후 경험한 임상적인 수준의 공황장애와 외상후스트레스장애의 기원에서 살펴볼 수 있 다. 2012년, 지구를 침공한 외계 종족을 전멸시키기 위해 세 계안전보장이사회 위원들이 민간인들의 희생을 감수하고서 외계 종족이 모여 있는 맨해튼에 핵미사일을 발사하라는 명 령을 내리고 실제로 핵미사일이 투하되자 스타크는 가까스 로 포털을 통해 지구 밖으로 핵미사일을 날려보내는 데 성 공한다. 스타크의 아버지 하워드 스타크는 과거 맨해튼 프로 젝트를 통하여 핵폭탄을 만드는 데 기여한 자이다. 세계안전 보장이사회 위원들의 결정은 생전 하워드 스타크의 평소 신 념과 매우 유사하다. 핵폭탄을 지구 밖으로 날려보냄으로써 세계안전보장이사회 위원들의 결정을 실제적으로 무효화한 스타크는 무의식적으로는 아버지를 넘어선(살해한) 것이다. 스타크는 의식적으로는 핵폭발의 위기로 인한 절멸의 공포 와 불안을 경험하지만, 무의식적으로는 살부 충동의 상징적 실현으로 인한 죄책감과 처벌 불안을 경험하였던 것으로 보 인다. 뉴욕 전투 이후 스타크는 핵무기를 날려보내는 내용의 꿈을 반복해서 침습적으로 꾸게 되고 강렬한 불안감을 느낀 다. 스타크의 발현몽(manifest content) 아래에는 오이디푸 스 갈등(oedipal conflict)과 관련된 잠재몽(latent content)이 놓여 있다고 해석할 수 있다.

\section{자기 심리학(Self psychology)을 이용하여 이 둘을 연결하기 (Link)}

스타크의 핵심적인 어려움, 문제, 패턴은 자존감의 조절인 것으로 보인다. 스타크는 자신감에 넘치고 거만해 보이지만 자존감을 위협받게 되면 빠르게 불안해지고 분노하며 큰 충 격을 받는다. 인공지능 시스템 자비스, 여비서 페퍼 포츠, 보 디가드이자 놀이 친구 해피 호건, 단짝 친구 제임스 로드, 대 저택, 슈퍼카, 아이언맨 슈트 등을 통해 확인할 수 있듯이 스 타크는 자존감을 높이고자 거울반응(mirroring), 이상화 (idealizing), 분신 혹은 쌍둥이(alter ego/twinship)의 무의식 적 소망을 충족시켜 줄 자기대상(selfobject)을 자기를 둘러 싼 환경의 변형을 통하여 끊임없이 추구한다. 아이언맨이 탄 
생한 최초의 계기가 된 아프가니스탄 피랍 사건에서 스타크 가 상심하고 분노한 지점은 테러리스트들의 부당한 요구나 협박이 아니었고 심장에 박힌 포탄의 파편으로 곧 죽음을 앞두고 있다는 사실도 아니었다. 자신이 발명한 무기가 세계 평화를 위해서가 아니라 테러리스트들에 의해 악용되고 있 다는 사실이 스타크의 정체성 감각과 자존감을 무너뜨렸던 것이다. 자신이 지향하는 이상과 가치(ideals and values), 그 리고 포부(ambitions)가 무너지고 자신에 대한 좋은 느낌을 갖지 못할 때 스타크는 자기애적 손상(narcissistic injury)을 경험하고 이에 대한 반응으로 자기애적 격노(narcissistic rage)를 보이며 자신에 대한 좋은 느낌과 상처(무너진 이상 과 가치 그리고 포부)를 회복(restore)하기 위한 노력(혹은 방어)의 일환으로 슈트를 개발하고 업그레이드한다.

스타크의 발달 및 과거력에서 가장 두드러진 부분은 아버 지와의 관계에서 비롯된 문제로 보인다. 스타크의 부모(특 히 아버지)는 스타크에게 공감적인 반응을 제공해 주지 못 했다. 적절한 자기대상(selfobject)을 경험하지 못하여 건강 한 자기 감각(sense of self)을 적절히 발달시키지 못한 스타 크는 수많은 자기대상을 스스로 만들어가며 자신에게 주어 진 유해한 초기 양육 환경과 조건(condition)에 대해 반격 (fight) 혹은 과다보상(overcompensation)하려 애썼던 것으 로 보인다. 세계 및 우주 평화라는 이상과 가치가 표상하는 이상화된 부모 이마고(idealized parental imago)와 평화의 수호자가 표상하는 과대자기(grandiose self)에 몰두하는 스 타크의 모습은 발달 및 과거력에서 결핍되었던 무의식적 욕 구에 대한 과다보상적 노력으로 보인다.

스타크는 의식적으로는 아버지의 전부를 미워했다고 느 꼈지만 무의식적으로는 아버지의 일부(발명품의 개발과 업 그레이드에 몰두하는 모습, 지성, 부, 명예, 아버지가 추구하 는 이상과 가치 등)를 좋아하였던 것으로 보인다. 아버지의 좋은 부분을 함입하고 동일시함으로써 자신이 몹시 미워하 고 있다고 말하는 아버지의 모습을 부분적으로(실제로는 매 우 흡사하게) 닮게 되었던 것이다. 스타크가 아버지와 어머 니가 죽음을 맞이한 여행을 떠나기 직전 아버지에게 따스한 말을 건네지 못했던 과거에 대하여 복잡한 심정을 표현하는 것도 스타크의 아버지에 대한 이러한 무의식적 양가감정과 관련이 있는 것으로 보인다.

타노스에게 패배한 스타크는 우주의 평화라는 이상과 가 치(ideals and values), 그리고 이를 지키는 평화의 수호자라 는 포부(ambitions)가 돌이킬 수 없이 무너졌다는 생각에 심 한 우울감(melancholia)을 느꼈던 것으로 보인다. 이를 만회 할 수 있는 기회를 얻게 된 스타크는 자신이 죽음에 이르게 되리라는 것을 알면서도 또한 이것이 사랑하는 가족에게 큰
상처가 될 수밖에 없다는 것을 어렴풋이 알면서도 자기애적 욕구의 진행[필연적(inevitable)인 죽음의 충동(Thanatos)마 저 거스르려 하는, 물론 역설적으로 죽음에 이르긴 했지만] 을 멈출 수가 없었던 것으로 보인다.

또한 아버지도 달성하지 못한(패배한) 세계와 우주 평화 라는 이상과 가치, 그리고 이를 구현하는 수호자로서의 포부 에 몰두하는 스타크의 모습은 아버지를 넘어서려는(살해하 려는) 그의 오이디푸스 갈등을 보여주기도 한다

\section{치료 가이드로서의 정신역동적 공식화}

정신역동적 공식화 과정을 통하여 스타크가 겪는 어려움, 문제, 패턴을 스타크의 자기 발달(the development of the self)에 연결할 수 있었다. 비록 스타크는 결국 사망했으나, 이는 스타크와 같은 사람에 접근하는 치료자의 치료 전략이 보다 건강한 자기 감각을 발달시키도록 돕는 것에 초점을 맞추어야 한다는 점을 시사한다.

스타크와 유사한 정신역동을 지닌 사람이 정신치료를 위 해 내원한다면, 스타크에 대한 치료 목표와 마찬가지로 건강 한 자기 감각을 발달시키도록 돕는 것에 초점을 맞추어야 한다. 건강한 자기 감각의 발달은 치료적 관계 자체를 통해 일어난다(Cabaniss 등 2013). 자기심리학의 관점에서는 환 자는 치료자가 자기대상 기능을 수행하기를 기대한다. 자기 대상 기능은 자기 감각(sense of self)을 안정화(stabilize)하 고 회복(restore)시키며 살아있도록 돕는 것이다. 이런 유형 의 환자는 치료자를 독립적인 사람으로 대하는 것이 아니라 자신이 통제할 수 있는 자신의 연장(extensions of oneself) 으로 대하게 된다. 치료자와 관계 형성은 발달 과정에서 최 적으로 완성되지 않은 자기의 발달 과정이 재활성화되는 계 기가 된다. 환자는 치료자를 이상화하고, 동시에 치료자가 자신을 반사해 주길 기대한다. 치료자는 이러한 전이에 대해 너무 일찍 해석해 주기보다는 이러한 전이가 무성하게 자랄 수 있도록(flourish) 일단 두고 보아야 한다. 이러한 전이의 영향 아래서 환자는 이해받는 느낌, 살아있는 느낌, 하나로 연결되어 있으면서도 통제할 수 있는 느낌을 경험한다. 이러 한 긍정적인 경험을 배경으로, 치료자는 환자가 원하는 대로 모든 것을 만족시켜 주지 않음으로써 환자로 하여금 공감적 실패(empathic failure)를 느끼도록 하고 그에 따른 좌절과 분노를 적절하게 경험할 수 있도록 해 준다. 그리고 적절한 시기를 살펴 치료자는 이러한 경험들을 해석해 주며 환자와 이에 대해 상의할 수 있으며, 이를 통해 환자는 자신의 심리 를 보다 분명하고 정확하게 이해할 수 있다.

스타크는 뉴욕 전투의 핵 위기를 경험한 뒤 임상적인 수 준의 공황장애와 외상후스트레스장애의 증상을 호소하지만 
브루스 배너(헐크) 이외에 다른 누군가에게 자신이 겪고 있 는 정신적 어려움에 대해 털어놓은 적이 없었다. 더군다나 영화 ‘아이언맨 3' 말미에 제시되듯, 브루스 배너는 스타크와 의 면담 도중 졸고 있었고 자신이 박사이긴 하지만 정신건 강 관련 분야의 박사도 아니며 수련도 받지 못했다고 고백 하였다. 스타크는 정식으로 정신치료를 받지는 못했지만 여 러 극적인 계기를 통하여 성장해 가며 어느 정도의 자기 성 찰을 달성하고 대인관계의 어려움을 비교적 잘 극복하여 지 속적인 자기의 발달을 보여준 사례에 해당된다. 그러나 병적 자기애와 건강한 자기애를 명확히 구별하여 딱 한 가지로만 스타크의 자기애를 명명(labeling)하는 것은 매우 어려운 일 이다. 어떤 행동의 의미를 살펴볼 때 자기 자신에게는 병적 인 자기애적 행동이지만 타인들에게는 이타주의에 기여하 는 건강한 자기애적 행동일 수 있기 때문이다. 인피니티 스 톤을 이용하여 타노스를 죽이고 자신도 죽음을 맞이하는 스 타크의 모습은 인류의 구원을 위하여 자신의 사적인 행복을 포기하는 순교자적 피학성을 보이기도 한다. 정신역동적 공 식화를 통해 살펴보았을 때, 스타크가 적절한 시기에 정신분 석 혹은 정신분석적 정신치료를 받은 뒤 자신의 심리를 보 다 분명하고 정확히 이해할 수 있었다면 스타크의 운명 혹 은 영화 '어벤져스: 엔드게임'의 결말이 바뀔 수도 있지 않았 을까 하는 가정을 해 본다.

\section{결 론}

아이언맨 사례의 정신역동적 공식화를 통하여 토니 스타 크의 심리를 밝힐 수 있었다. 발달 과정에서 아버지와의 관 계에서 문제가 있었던 스타크는 아버지를 미워하면서도 아 버지를 동일시한 것으로 보인다. 뛰어난 지적 능력에 반하여 공감 능력이 낮고, 과대적이고 자기애적 인격 성향을 보이는 스타크는 악당들과의 싸움을 통해서 자신을 성찰하는 계기 들을 계속 만들었던 것으로 보인다. 죽음을 무릅쓰고 인류를 구하려는 시도는 무의식적으로는 스타크의 자기의 회복(the restoration of the self)을 위한 노력이자 동시에 오이디푸스 갈등으로서의 의미가 있다. 인생의 후반부로 갈수록 대인 관 계가 끊임없이 개선되고 연인 페퍼 포츠와 결혼하여 자식을
낳고 결혼 생활을 잘 유지한 부분은 스타크의 자기애가 성 장하고 발달하여 건강한 측면이 있었음을 시사한다. 스타크 가 겪고 있는 어려움, 문제, 패턴을 자기의 발달과 연결시키 고, 스타크가 보다 더 건강한 자기 감각을 발달시키도록 치 료적으로 도와야 함을 본 사례의 정신역동적 공식화를 통해 이해할 수 있었다.

정신건강의학과의 임상 현장에서 정신역동적 공식화는 환자의 진단과 치료에 있어서 필수적인 작업이다. 연구자는 영화 속 한 인물의 사례를 중심으로 정신역동적 공식화를 수행하였고 영화를 포함한 예술이라는 풍부한 자원이 정신 역동적 공식화의 교육 및 수련 재료로 활용될 수 있다는 것 을 제시하였다.

\section{Acknowledgments}

None

\section{Conflicts of Interest}

The authors have no potential conflicts of interest to disclose.

\section{Author Contributions}

Conceptualization: Seungrie Han. Data curation: Seungrie Han. Formal analysis: Seungrie Han. Investigation: Seungrie Han. Methodology: Seungrie Han. Project administration: Kyungmin Park. Resources: Seungrie Han. Supervision: Kyungmin Park. Validation: Kyungmin Park. Writing — original draft: Seungrie Han. Writingreview \& editing: Seungrie Han.

\section{ORCID iDs}

Kyungmin Park: https://orcid.org/0000-0002-5069-2944

Seungrie Han: https://orcid.org/0000-0003-1679-8937

\section{REFERENCES}

Cabaniss DL, Cherry S, Douglas CJ, Graver RL, Schwartz AR. Psychodynamic formulation. Chichester: Wiley-Balckwell;2013.

Freud S. Formulations on the two principles of mental functioning. The standard edition of the complete psychological works of Sigmund Freud, Volume XII (1911-1913): the case of Schreber, papers on technique and other Works. London: Hogarth press;1911. p.213-226.

Freud, S. Some character-types met with in psycho-analytic work. The standard edition of the complete psychological works of Sigmund Freud, Volume XIV (1914-1916): on the history of the psycho-analytic movement, papers on metapsychology and other works. London: Hogarth Press;1916. p.309-333. 